\title{
Brussels bids for Framework 'top-up' funds
}

Munich. Edith Cresson, the European Union (EU)'s research commissioner, last week won the support of her 19 fellow commissioners for a bid to allocate ECU700 million (US\$925 million) in potential 'topup' funds to the work of five task forces set up to promote the development of new technologies in Europe under the EU Framework programme.

The move could end the hopes of Europe's national research councils that some of this money would be used to improve the coordination of their basic research with the goals identified by the task forces, and to provide large awards to a selected group of leading research teams, comparable to Germany's Leibnitz prize.

But while disagreement remains over how the money should be used, there is also concern about whether it will in fact materialize. The proposed top-up fund represents ECU600 million to be held in reserve for the fourth Framework programme, which runs from 1995 to 1999, and ECU100 million for the research programmes of the atomic energy agency Euratom.

The precise allocation of the money, initially left undefined on the grounds that it would be used to fine-tune spending on both programmes, has to be approved by the commission, the European parliament and the European Council next year. Some finance ministers are already arguing for a sharp reduction.

Cresson, in contrast, is already firm on how she would like the full money to be spent. Together with Neil Kinnock and Martin Bangemann, commissioners for transport and industry respectively, she has set up task forces to investigate how better

\section{EMBO seeks stronger voice on policy}

Heidelberg. The European Molecular Biology Organization (EMBO) wants to raise its profile in Europe by reorganizing its 850 individual members into a type of academy of sciences able to contribute a collective voice to debates on European science policy.

Earlier this month, EMBO's council agreed that it needs to make more use of its members in helping to promote molecular biology in Europe, primarily through its increasingly popular short- and long-term fellowships, as well as specialist courses and workshops.

At present, the main role of EMBO members, who are elected on the basis of academic achievement, has been to interview candidates for fellowships. The council would now like to hold annual meetings of its members to discuss science policy issues affecting molecular biology.

The EMBO council also agreed to pay for EMBO members wishing to help coordination of EU research could promote the development of new technologies in areas such as the 'clean' car and vaccines against viral diseases (see Nature 374, 206; 1995).

The development of safe water supplies was recently added to the portfolio for the benefit of Mediterranean countries, and it is planned to feed the results of the task forces' work into the fifth Framework programme, which begins in 1999.

Some of the task forces have already made significant progress, and coordination plans are being put into practice. Earlier this month, for example, Cresson announced a three-month delay to the second call of pro-

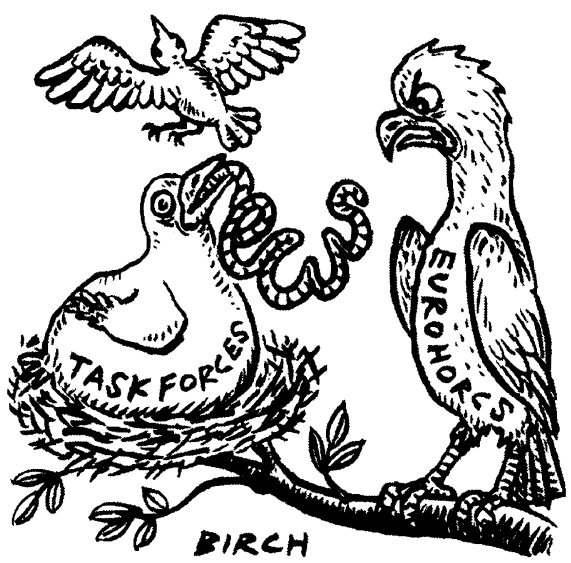

posals for the technology-orientated ECU1,200 million Brite-EuRam research programme, to line up with the December call for the industry commission's major ESPRIT programme.

The delay will give managers of the BriteEuRam programme time to realign its scope with the ideas of the task forces concerned with transport. A spokesman for the programme says that focusing its aims will have a second benefit; its original broad remit meant that the programme was heavily oversubscribed in the first call for proposals, and the acceptance rate was only 18 per cent.

The commission argues that EU member states should pay the top-up fund in full because of the need to coordinate research in specific fields to ensure the general competitiveness of European industry. Priorities include the next generation of cars and aircraft, multimedia education technologies, integrated transport systems and environmental technologies, including the protection of water supplies and a Euratom programme on the security of eastern European nuclear reactors.

The broad proposal will be considered next week by the research ministers of EU states. But it may have to be adjusted before being put to the full European Council at the end of the year if the finance ministers, meeting next month, refuse to approve the full sum.

Meanwhile, the heads of Europe's national research councils - known collectively as Eurohorcs - meeting in Venice earlier this month, decided to seek the support of the European Science and Technology Assembly (ESTA), the commission's 100 -strong advisory panel, for its own ideas of how the top-up money should be spent.

The Eurohorcs are worried that the task forces' industrial aims may result in basic research being ignored, and would therefore be prepared, with the commission, to finance basic research projects relevant to the task forces. The exact nature of the coordination would depend on how much of the funding for the proposed projects would come from the commission and how much from the research councils themselves.

At the suggestion of Wolfgang Fruhwald, tries in taking part in its activities. The number of applications for EMBO's special programme of six-month fellowships for east Europeans has been falling steadily.

According to Gannon, this may be because inadequate facilities means that returning scientists are unable to put into practice what they have learnt in Western Europe. EMBO is to invite its members to visit molecular biology laboratories in such countries for a week, to try to improve the match between the specific needs of the laboratories and appropriate projects in Western Europe, and to help the laboratories to apply successfully for foreign grants.

EMBO will also finance plenary lectures at national and international symposia, particulary in east European countries, in order to stimulate support for the European Molecular Biology Laboratory (EMBL) in Heidelberg.

A.A. president of Germany's Deutsche Forschungsgemeinschaft, they would also like ECU20 million set aside for ten awards to leading research teams, a scheme already successfully applied in Germany.

The research council heads argue that both schemes would improve the scientific credibility of the research commission's work. But at its meeting last week, ESTA declined to decide whether to support the two proposals because of uncertainty over the amount of top-up funds, according to the assembly's chairman, Jan Boorgman.

A spokesman for Cresson's cabinet says that she was prepared to consider any formal proposal for the use of the top-up funds, but doubted whether she would agree to split the money into relatively small sums.

Alison Abbott 